\title{
PRE-TREATMENT OF INDUSTRIAL MINERAL OIL WASTEWATER USING RESPONSE SURFACE METHODOLOGY
}

\author{
EMMANUEL KWEINOR TETTEH, SUDESH RATHILAL \& MARTHA NORO CHOLLOM \\ Department of Chemical Engineering, Durban University of Technology, South Africa
}

\begin{abstract}
This study focuses on the process optimization of coagulation floatation by cross-interaction effects of the following multiple factors: $\mathrm{pH}$, coagulant dosage and floatation time on the response of chemical oxidation demand (COD), soap oil and grease (SOG), turbidity and total suspended solids (TSS). The results from the response surface methodology incorporated with Box Benken design (BBD) models reveals significant correlations and interactions between the manipulated and response variables. To establish the optimum pre-treatment conditions, the experiment used the design BBD, using Design Expert (Design Expert 10.0.3) software. This ensures that the process engineers and scientists gain a better understanding of the practical application of the experimental results over the conventional method of one-factor-at-time (OFAT). The recent trend in industrialization and population growth has indeed deepened the demand on the world's energy (oil) and water resources. However, the need to meet the significance of energy and water for sustainable social economy growth and development has resulted in extremely adverse effects on water and environmental pollution. South Africa, well known as a water scarcity country, has also intensified its policy and increased fines for offenders who do not meet its regulations and discharge limits. In this context, the treatment of industrial mineral oil wastewater, which is regarded as hazardous and harmful to the environment, derived from petrochemical and oil refinery industries, has a recovery value. This has raised attention for systematic technology and approach in recovering oil and water for reuse to conserve the supply of fresh water and energy resources. Keywords: floatation, response surface methodology, soap oil and grease, oil water separation.
\end{abstract}

\section{INTRODUCTION}

Modernisation has shown that the rate of a country's economy and development can be measured by the utility of energy and water per household. For instance, crude oil provides $60 \%$ of South Africa's energy followed by coal, synthetic fuels and natural gases, where specific water intake (SWI) of local refineries vary between 0.51 and $0.67 \mathrm{~m}^{3} / \mathrm{t}$ of crude. In addition, most of these industries discharge approximately $46 \%$ of the water intake as mineral oil wastewater (MOW) with the major contaminant such as chemical oxidation demand (COD), soap oil and grease (SOG), turbidity and total suspended solids (TSS) [1]. However, the oil droplets in the MOW contains emulsified, dispersed, dissolved and spilled oils generated from the petroleum industry during the primitive refining of the crude oil, ships slops, petroleum off spec and during transportation [2], [3].

These excess amounts of MOW causes severe pollution, oxygen depletion, imbalance ecosystem and human health risks when discharged into the environment without treatment. In addition, the unrecovered oil contributes to the presence of a high content of degradable organic compounds with great capacity of penetration into the ground that pose threats to the ground water [4], [5]. Tir and Moulai-Mostefa [6] reported that depending on the pollutants and the source of the MOW; there are several wastewater treatment methods to ensure good effluent quality before discharge into the sewer system. However, there are some limitations associated with some of these methods such as operational cost and inefficient operation leading to downstream problems such as an increase in chemical oxygen demand (COD) and SOG [7], [8]. An improper operation of a municipal wastewater treatment plant (WWTP) led 
to the pollution of various water bodies thereby posing health and social economic threat to the needy [9]. In South Africa, to address and balance the environmental protection, economic viability of recovered oil (lubricant oil) and water (irrigation) has led to strict regulation for the discharge of the effluent [1]. Therefore, the need for one or combination of many methods to achieve effective purification, separation efficiency and lower the effluent quality and cost is attracting the attention of many scholars [10], [11].

Coagulation, which is a chemical treatment method, followed by a separation process such as dissolved air floatation (DAF) are mostly used in the MOW treatment [6]. The chemical treatment is usually done to improve the water quality via the addition of coagulants with small amount of acid $(\mathrm{H}+)$. The breaking of emulsions chemically to remove oils can be done via addition of salts ( such as $\mathrm{Al}^{3+} \mathrm{Fe}^{3+}$ or $\mathrm{Ca}^{2+}$ ), polymers, bentonites and $\mathrm{pH}$ adjustment [8], [12]. In addition, $\mathrm{pH}$ adjustment by either increasing (lime, $\mathrm{NaOH}$ ) or decreasing $\left(\mathrm{HCl}, \mathrm{H}_{2} \mathrm{SO}_{4}\right) \mathrm{pH}$ is very sensitive, where overdose or underdose can lead to inefficient treatment and corrosion of the piping system and equipment [13]. This destabilises the oil emulsion, breaks and slows down the interfacial force between the oil droplet and the continuous dispersed phase. The significance of chemical pre-treatment before floatation is to neutralise the oil charge, absorb the oil-dispersed phase, and hence increase the interfacial bridging to precipitate. This results in stability and increases the coagulated oil droplet size to float for separation [14].

The application of DAF works under the principle of rising velocity, which is a costeffective alternative to sedimentation. In this process air is induced at the bottom of the floatation column, where the abundant free micron bubbles spontaneously boils out and adheres to the oil droplet, coagulate then cause rise up to float to the surface to be separated. According to Li et al. [2], to achieve $95-97 \%$ separation of oil water containing emulsified oil within a floatation time of 5 minutes, the contact time between the oil droplet and the air bubbles is significant. This is due to the complex mechanism between the bubbles-oil droplet attachment process; where the fluid viscosity, oil droplet and bubble size and the interfacial force are affected by the induction and hold up time [15].

To adapt this concept from a bench scale and implement on a full scale, to achieve high treatment efficiency with low chemical usage and desirable water qualities, there exist some limitations to control the process. This is due to variations of the water quality (inlet and outlet). In addition, lack of a predictive model to incorporate the operating conditions (coagulant dosage, $\mathrm{pH}$ and floatation time) to compensate the series of treatment processes as well as for decision making [3].

The response surface methodology (RSM) predictive model provides a closer result of the response towards the desirable water quality and that makes it the alternate option for process optimisation. The RSM is a statistical tool that integrates both the independent variables and the experimental data input and then finally generate a predictive model as the output or response. Therefore, its application is widely acceptable due to rapidity and fewer number of experimental runs required, well-designed regression analysis, evaluation and identification of the most significant input factors that can affect the process and help the researcher to focus on identifying and controlling [16]. In addition, the use of one-factor-at-time (OFAT) method is difficult to determine the interactions between the factors and establish the relationship between the input and output variables which is very crucial in the application of multiple factors.

The optimisation of multivariate procedure requires two variables viz. the responses and the factors. The responses are the dependent variables, their values depend on the levels of the factors. The arrangement of the Box Behnken Design (BBD) is based on the selected 
points from the three-level factorial [17]. This allows the coefficient of first-second order estimation to be the significant eqn (1).

$$
\mathrm{Y}=\beta_{0}+\sum_{\mathrm{i}=1}^{\mathrm{n}} \beta_{\mathrm{i}} \mathrm{X}_{\mathrm{i}}+\sum_{\mathrm{i}=1}^{\mathrm{n}} \beta_{\mathrm{ii}} \mathrm{X}_{\mathrm{ii}}^{2}+\sum_{\mathrm{i}<\mathrm{j}}^{\mathrm{n}} \beta_{\mathrm{ij}} \mathrm{X}_{\mathrm{i}} \mathrm{X}_{\mathrm{j}}+\varepsilon,
$$

where $\mathrm{X}_{\mathrm{i}} \mathrm{X}_{\mathrm{j}}$ represents the interaction terms, and $\beta_{i i}$ and $\beta_{i j}$ represents the coefficients of the interaction factors respectively.

Therefore, implementing the RSM-BBD to evaluate the relationship, and interactions of the factors involves the following steps:

- Design of the experiment: three-level designs such as the Box Behnken Design (BBD).

- Regression and statistical analysis, developing of models and graphical representation of the response surface (3D, contour plots).

- Optimisation of the variables using the response model to achieve the desirable target.

- The use of the analysis of variance to check the validity of the models by comparing the predicted model and the experimental values.

In this study the goal is to optimise multiple factors on coagulation floatation treatment process, improve a polymeric coagulant dosage and stabilise the outlet water quality. Pre-treatment optimisation to serve this purpose was carried out using DAF jar test with polymeric chloride (Z553D) coupled with the response surface methodology. The BBD was used to evaluate the effects and interactions of $\mathrm{pH}$, coagulation dosage and floatation time on a local South African oil refinery WWTP effluent quality in the KwaZulu-Natal province.

\section{MATERIALS AND METHODS}

\subsection{Pre-chemical treatment mechanism (Jar test)}

The DAF jar test used in this study consists of six identical Perspex conical bottom floatation jars, with each volume capacity of $1200 \mathrm{ml}$, diameter of $100 \mathrm{~mm}$ and a sample point on each side of the jars. The $\mathrm{pH}$ of the sample obtained from the oil refinery was first adjusted with either $1.0 \mathrm{M} \mathrm{H} 2 \mathrm{SO} 4$ or $1.0 \mathrm{M} \mathrm{NaOH}$ stock solution to suit the runs requirement. Then the required dosage of the Z553D was also added to the sample with rapid mixing of $250 \mathrm{rpm}$ for 2 minutes. To enhance the formation of the oil droplet flocs, the stirring speed was then reduced to $30 \mathrm{rpm}$ for 15 minutes. Immediately after the slow mixing time overlap, compressed air was introduced at the bottom via an air release nozzle from an $8 \mathrm{~L}$ air saturator at the desired pressure of $350 \mathrm{kPa}$. The mixture was left to float per the floatation time required.

\subsection{Optimisation using Box Behnken Design (BBD)}

The first step was to identify the optimum range for the chemical additives ( $\mathrm{pH}$ and coagulant dosage) at a fixed floatation time of $15 \mathrm{~min}$ and coagulant dosage of $50 \mathrm{mg} / \mathrm{L}$. The $\mathrm{pH}$ values of 2, 4, 6, 8 and 10 were tested. From the optimum $\mathrm{pH}$ obtained and the fixed floatation time as stated earlier, the coagulant dosage was also evaluated at 10, 20, 30, 40, 50 and $60 \mathrm{mg} / \mathrm{L}$.

Lastly, to overcome the limitations of OFAT and determine the overall optimum conditions, the BBD in the RSM (Design Expert 10.0.3) was used to generate the experimental matrix and the outcome was used to find the optimal variable and the response model equation to enhance the performance of the Z553D for the treatment of the MOW. 
The responses identified for this study were COD (Y1), SOG (Y2), TSS (Y3) and turbidity (Y4). The COD, turbidity and TSS were measured with the Hach DRB 3900 spectrophotometer, Hach $2100 \mathrm{~N}$ and Hach DR/890 portable colorimeter respectively. The South African Bureau of Standards (SABS) technique 1051 was adapted for the analysis of SOG using Dichloromethane for the oil extraction. Three distinct factors were also identified as the manipulating variables affecting the responses. This included $\mathrm{pH}(\mathrm{A})$, coagulant dosage (B) and floatation time (C) with their levels shown in Table 1.

The percentage removal of the response was calculated using eqn (2):

$$
\mathrm{Y}_{\mathrm{n}}(\%)=\frac{\mathrm{y}_{0}-\mathrm{y}_{\mathrm{n}}}{\mathrm{y}_{0}} \times 100,
$$

where $Y_{n}, y_{0}$ and $y_{n}$ represent the demanded response (water quality), initial and final water quality respectively.

\section{RESULTS AND DISCUSSION}

The chemical pre-treatment before floatation allows the oil droplet, colloids, organics and suspended solids to agglomerate into larger aggregates for stability and buoyancy in order to float. In addition, it was observed that the air bubble size depended on the air saturator pressure applied. This increased the air bubble-oil droplet attachment via the mechanism of collision, adhesion and stabilisation [14].

Evaluation of $\mathrm{pH}$, coagulant dosage and floatation time to identify the most important factor and their state of interest was seen as important, hence reducing downstream treatment cost and adding value to recovered oil and water. The response COD, SOG, TSS and turbidity were found to be dependent on the input factors. Where the change in response was found to be directly proportional to the effect caused by the change in level of the factor and where the change was caused by two factor levels it was deduced that there is interactional effects. The results obtained from the BBD matrix is represented in Table 2.

\subsection{Effects of $\mathrm{pH}$}

The adjustment of the $\mathrm{pH}$ has significant effect on the separation due to the negative charge of the oil droplet. This affects the nature and the occurrence of the flocs, thus neutralising the surface charge. It was found that lower $\mathrm{pH}$ resulted in the oil droplet flocs becoming unstable and enlarged resulting in them being easily separated. Fig. 1 represents the effect of $\mathrm{pH}$ on the removal efficiency of the response contaminants. It can be seen that the charge neutralisation and precipitation of the oil droplet and other particles were feasible for a narrow range of $\mathrm{pH} 4-6$ for effective separation. Thus above $85 \%$ of COD, SOG and turbidity were removed at a floatation time of $15 \mathrm{~min}$ and coagulant dosage of $50 \mathrm{mg} / \mathrm{L}$. In the case of TSS above $70 \%$ was removed. However, $\mathrm{pH}$ has a lesser significant influence on TSS and turbidity removal unlike, COD and SOG. Increasing the $\mathrm{pH}$ decreases the efficiency removal hence the lower the $\mathrm{pH}$ the better the removal. Therefore, the $\mathrm{pH}$ was adjusted to within 4 and 6 for the process optimisation.

Table 1: RSM - Box Behnken Design matrix.

\begin{tabular}{llcl}
\hline Input factors & \multicolumn{3}{c}{ Range or levels } \\
Coded values & -1 & 0 & 1 \\
\hline $\mathrm{A}: \mathrm{pH}$ & 4 & 5 & 6 \\
$\mathrm{~B}:$ Coagulant dosage $(\mathrm{mg} / \mathrm{L})$ & 30 & 40 & 50 \\
C: Floatation time $(\mathrm{min})$ & 10 & 15 & 20 \\
\hline
\end{tabular}


Table 2: Box Behnken Design matrix.

\begin{tabular}{|l|l|l|l|l|l|l|l|}
\hline $\begin{array}{l}\text { Standard } \\
\text { run }\end{array}$ & $\mathrm{pH}$ & $\begin{array}{l}\text { Coagulant } \\
\text { dosage } \\
(\mathrm{mg} / \mathrm{L})\end{array}$ & $\begin{array}{l}\text { Floatation } \\
\text { time }(\mathrm{min})\end{array}$ & $\begin{array}{l}\text { COD } \\
(\mathrm{mg} / \mathrm{L})\end{array}$ & $\begin{array}{l}\text { SOG } \\
(\mathrm{mg} / \mathrm{L})\end{array}$ & $\begin{array}{l}\text { Turbidity } \\
(\mathrm{NTU})\end{array}$ & $\begin{array}{l}\text { TSS } \\
(\mathrm{mg} / \mathrm{L})\end{array}$ \\
\hline 1 & 0 & 0 & 0 & 87 & 89 & 80 & 71 \\
\hline 2 & 0 & 0 & 0 & 84 & 90 & 83 & 70 \\
\hline 3 & 0 & -1 & 1 & 80 & 70 & 73 & 63 \\
\hline 4 & -1 & 1 & 0 & 88 & 91 & 87 & 76 \\
\hline 5 & 1 & 0 & -1 & 79 & 75 & 78 & 66 \\
\hline 6 & 0 & 0 & 0 & 84 & 86 & 81 & 69 \\
\hline 7 & 0 & 1 & 1 & 89 & 88 & 86 & 74 \\
\hline 8 & 1 & 1 & 0 & 88 & 88 & 83 & 73 \\
\hline 9 & -1 & 0 & 1 & 77 & 83 & 83 & 68 \\
\hline 10 & 0 & 0 & 0 & 82 & 90 & 85 & 68 \\
\hline 11 & 1 & 0 & 1 & 77 & 84 & 84 & 67 \\
\hline 12 & -1 & -1 & 0 & 75 & 73 & 71 & 61 \\
\hline 13 & -1 & 0 & -1 & 79 & 84 & 80 & 66 \\
\hline 14 & 1 & -1 & 0 & 78 & 72 & 72 & 65 \\
\hline 15 & 0 & 1 & -1 & 89 & 90 & 84 & 73 \\
\hline 16 & 0 & -1 & -1 & 79 & 81 & 74 & 62 \\
\hline 17 & 0 & 0 & 0 & 83 & 88 & 82 & 61 \\
\hline
\end{tabular}

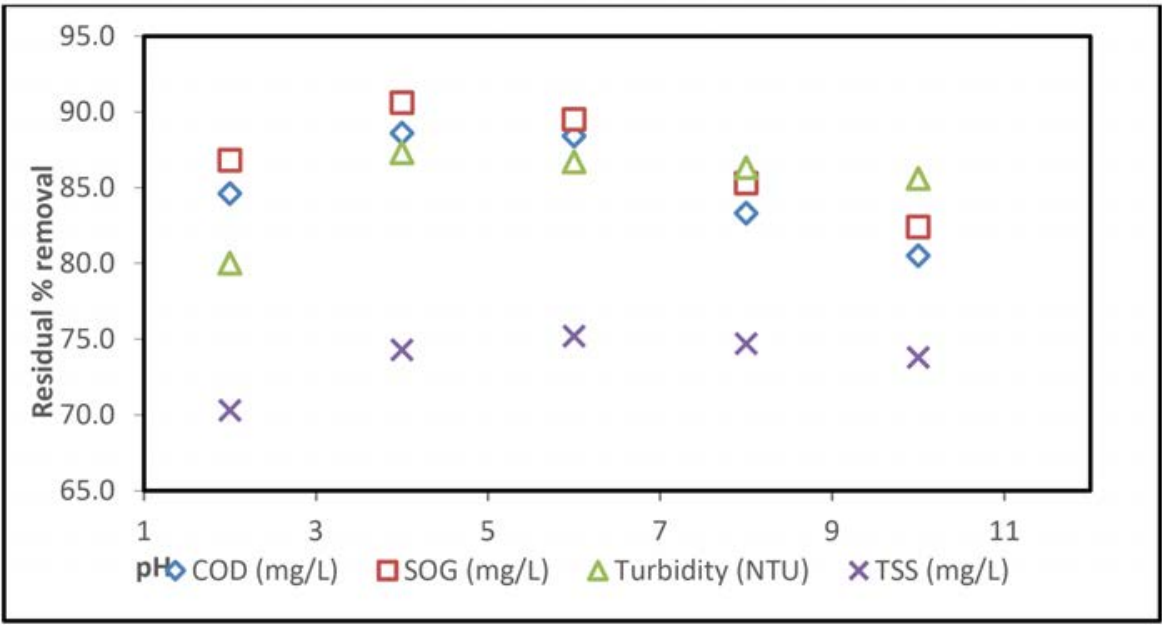

Figure 1: Effects of $\mathrm{pH}$ on response \% removal; coagulant dosage $50 \mathrm{mg} / \mathrm{L}$ and floatation time 15 min. 


\subsection{Effects of coagulant dosage}

To enhance oil water separation there must be a strong interfacial force between the oil-water, bubbles-water and bubbles-oil. However, the floatation mechanism depends solely on the collision that occurs between the air bubbles and the oil droplet. Hence, the addition of the Z553D intensifies the bridging and adsorption action, resulting in increased collisions and agglomeration as well as forming larger flocs.

In contrast, when the dosage exceeded the centre of limits stability resulted and the flocs easily broke thereby reducing the tendency to float rather settle as sludge [2]. Fig. 2 shows that the removal of the contaminants were more efficient within the coagulant dosage of $40-50 \mathrm{mg} / \mathrm{L}$, thus above $75 \%$ for TSS and that of COD, SOG and turbidity over $85 \%$ were being removed. On the other hand, at a coagulant dosage of $60 \%$, there is likelihood of an overdose or excess Z553D, which might have caused the increase of air-floc to agglomerate with slow rising velocity thereby decreasing the Z553D efficiency.

\subsection{Optimization using RSM}

The optimum conditions and the region of interest was determined using the RSM coupled with the BBD. On this basis, the data obtained from the experiment was used to study the effects and interaction towards the response. To justify the correlation that exists between the input and response variables, the analysis of variance (ANOVA) was used to test the statistical significance and the response model generated. The following are the empirical response regressions with their significant coded model terms:

$$
\begin{gathered}
Y_{1}=-19.75+40.35 A-1.275 B+2.325 C-4 A^{2}+0.0225 B^{2}-0.08 C^{2}, \\
Y_{2}=87.37-1.5 A+7.63 B-4.33 A^{2}-3.58 B^{2}, \\
Y_{3}=80.35+6.25 B \\
Y_{4}=67.82+5.63 B .
\end{gathered}
$$

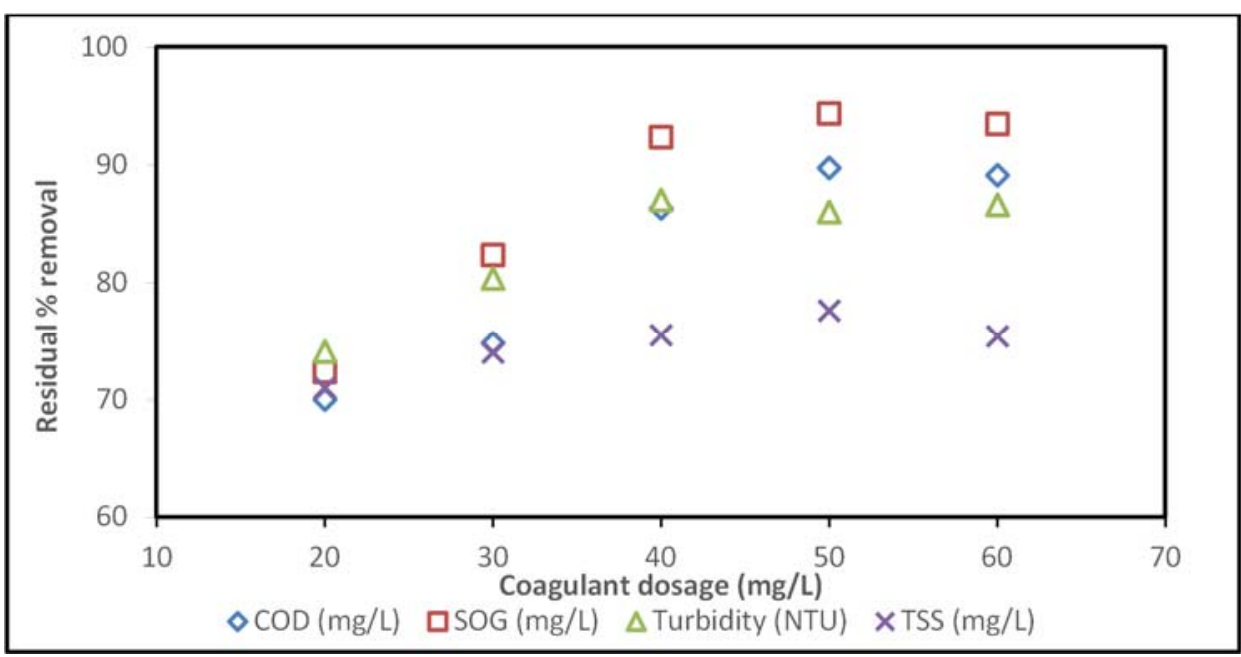

Figure 2: Effects of coagulant dosage on response \% removal; $\mathrm{pH} 5$ and floatation time $15 \mathrm{~min}$. 
To predict the response using the given level of each factor and to identify the relative response by comparing their coefficients, all the input terms must be in a coded form. The positive coefficient terms in eqns (3)-(6) signifies an increase on those terms will increase the percentage removal of the response. Whilst the negative terms suggest if not maintained at an optimum value, will lower the efficiency of the removal.

The quadratic and linear regressions selected were all found to be significant with low standard deviation and a high coefficient of determination (R2) values as shown in Table 3. The actual R2 for each of the response models were $0.93,0.90,0.77$ and 0.74 for Y1, Y2, Y3 and Y4 respectively. The ANOVA for all the responses in Table 4 also depicts that all the input variable terms in the response empirical models were all significant with $P$-values less than 0.05 . Also the lack of fit errors has no significant effects on the models.

Table 3: Summary of all response model statistics.

\begin{tabular}{|l|l|l|l|l|l|l|l|}
\hline Responses & $\begin{array}{l}\text { Model } \\
\text { Source }\end{array}$ & Std. Dev. & $\begin{array}{l}\text { Adeq. } \\
\text { Precision }\end{array}$ & Actual R & $\begin{array}{l}\text { Adjusted } \\
\mathrm{R}^{2}\end{array}$ & $P$-value & $\begin{array}{l}P>F- \\
\text { value }\end{array}$ \\
\hline COD & Quadratic & 1.51 & 13.69 & 0.93 & 0.90 & 19.23 & 0.0009 \\
\hline SOG & Quadratic & 3.65 & 10.64 & 0.90 & 0.80 & 6.54 & 0.0194 \\
\hline TSS & Linear & 2.5 & 14.61 & 0.77 & 0.76 & 3.43 & 0.1237 \\
\hline Turbidity & Linear & 2.41 & 13.59 & 0.74 & 0.73 & 2.6 & 0.1854 \\
\hline
\end{tabular}

Table 4: ANOVA for fits of all responses percentage removal.

\begin{tabular}{|l|l|l|l|l|l|l|}
\hline $\begin{array}{l}\text { Source / input } \\
\text { variable }\end{array}$ & $\begin{array}{l}\text { Sum of } \\
\text { squares }\end{array}$ & $\mathrm{df}$ & $\begin{array}{l}\text { Mean } \\
\text { square }\end{array}$ & -value & $\begin{array}{l}p \text {-value } \\
\text { Prob }>F\end{array}$ & \\
\hline $\mathrm{Y}_{1}$-model & 326.31 & 6 & 54.38 & 23.91 & $<0.0001$ & significant \\
\hline $\mathrm{A}$ & 68.28 & 1 & 68.28 & 30.01 & 0.0003 & \\
\hline $\mathrm{B}$ & 10.61 & 1 & 10.61 & 4.66 & 0.0562 & \\
\hline $\mathrm{C}$ & 15.58 & 1 & 15.58 & 6.85 & 0.0257 & \\
\hline $\mathrm{A}^{2}$ & 67.37 & 1 & 67.37 & 29.61 & 0.0003 & \\
\hline $\mathrm{B}^{2}$ & 21.32 & 1 & 21.32 & 9.37 & 0.012 & \\
\hline $\mathrm{C}^{2}$ & 16.84 & 1 & 16.84 & 7.4 & 0.0215 & \\
\hline Residual & 22.75 & 10 & 2.27 & & & \\
\hline Lack of Fit & 8.75 & 6 & 1.46 & 0.42 & 0.8381 & not significant \\
\hline Pure error & 14 & 4 & 3.5 & & & \\
\hline Cor total & 349.06 & 16 & & & & \\
\hline $\mathrm{Y}_{2}$-model & 624.03 & 4 & 156.01 & 11.71 & 0.0004 & significant \\
\hline A & 18 & 1 & 18 & 1.35 & 0.2677 & \\
\hline B & 465.13 & 1 & 465.13 & 34.92 & $<0.0001$ & \\
\hline $\mathrm{A}^{2}$ & 79.12 & 1 & 79.12 & 5.94 & 0.0313 & \\
\hline $\mathrm{B}^{2}$ & 54.08 & 1 & 54.08 & 4.06 & 0.0669 & \\
\hline Residual & 159.85 & 12 & 13.32 & & & \\
\hline Lack of Fit & 148.65 & 8 & 18.58 & 6.64 & 0.0426 & not significant \\
\hline Pure Error & 11.2 & 4 & 2.8 & & & \\
\hline Cor Total & 783.88 & 16 & & & & \\
\hline $\mathrm{Y}_{3}$-model & 312.5 & 1 & 312.5 & 50.2 & $<0.0001$ & significant \\
\hline
\end{tabular}


Table 4: Continued.

\begin{tabular}{|l|l|l|l|l|l|l|}
\hline $\begin{array}{l}\text { Source / input } \\
\text { variable }\end{array}$ & $\begin{array}{l}\text { Sum of } \\
\text { squares }\end{array}$ & $\mathrm{df}$ & $\begin{array}{l}\text { Mean } \\
\text { square }\end{array}$ & $F$-value & $\begin{array}{l}p \text {-value } \\
\text { Prob }>F\end{array}$ & \\
\hline B & 312.5 & 1 & 312.5 & 50.2 & $<0.0001$ & \\
\hline Residual & 93.38 & 15 & 6.23 & & & \\
\hline Lack of Fit & 78.58 & 11 & 7.14 & 1.93 & 0.2755 & not significant \\
\hline Pure Error & 14.8 & 4 & 3.7 & & & \\
\hline Cor total & 405.88 & 16 & & & & \\
\hline Y4-model & 253.12 & 1 & 253.12 & 43.47 & $<0.0001$ & significant \\
\hline B & 253.13 & 1 & 253.13 & 43.47 & $<0.0001$ & \\
\hline Residual & 87.35 & 15 & 5.82 & & & \\
\hline Lack of Fit & 24.55 & 11 & 2.23 & 0.14 & 0.9954 & not significant \\
\hline Pure error & 62.8 & 4 & 15.7 & & & \\
\hline Cor total & 340.47 & 16 & & & & \\
\hline
\end{tabular}

\subsection{The three-dimensional (3D) plot}

The sensitivity of the input variables towards the responses were represented graphically in $3 \mathrm{D}$ response surface plots. On this basis, the floatation time was kept constant (15 min) while the coagulant dosage and $\mathrm{pH}$ were varied within their designed range. This helped to identify the main factor, interactional effects and the optimum condition for decision making onto the large scale WWTP. The mutual interaction and high peak region between the coagulant dosage and $\mathrm{pH}$ was located at $45-50 \mathrm{mg} / \mathrm{L}$ and the $\mathrm{pH}$ within the range of 4.5-5.5, where over $80 \%$ of the contaminants were removed.

Fig. 3(a) shows the graphical representation of how the COD response varies as a function of the input variables (coagulant dosage and $\mathrm{pH}$ ). The peak of the curvature suggest that the optimum conditions to maximise the COD removal is well inside the design boundaries. In addition, $\mathrm{COD}$ removal increases with an increase in coagulant dosage at fixed $\mathrm{pH}$ and floatation time (5 and 15 minutes).It was found $91 \%$ of the COD was removed at coagulant dosage of $49 \mathrm{mg} / \mathrm{L}$.

Fig. 3(b) shows the relative effect of the input variables (coagulant dosage and $\mathrm{pH}$ ) on the removal of SOG. The removal of SOG increases with an increase in coagulant dosage at fixed $\mathrm{pH}$ (5). And a maximum removal of $92 \%$ was attained by using a coagulant dosage of $49 \mathrm{mg} / \mathrm{L}$.

Fig. 3(c) shows the 3D response plot for TSS removal showing the interaction effect of coagulant dosage and $\mathrm{pH}$. It was noted increasing the coagulant dosage had much impact on the removal than the $\mathrm{pH}$. And at coagulant dosage of $49 \mathrm{mg} / \mathrm{L}$, maximum removal of $86 \%$ TSS was attained.

Fig. 3(d) also shows the 3D response plot for the turbidity removal denoting the relative effect of the two input variables. It was noted that increasing the coagulant dosage had no significance effects to maximise the removal whiles the $\mathrm{pH}$ had no significant effect on the removal. And $73 \%$ as the maximum removal was attained. 


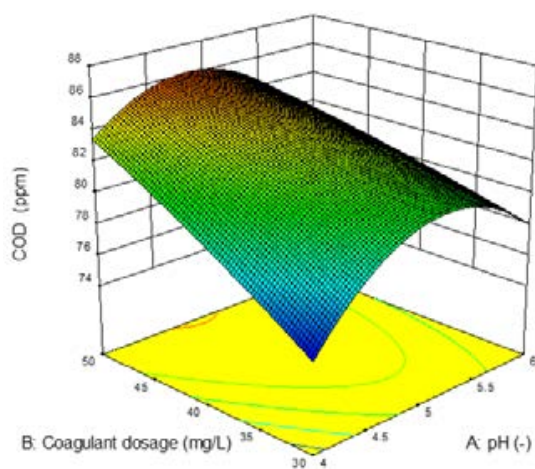

(a)

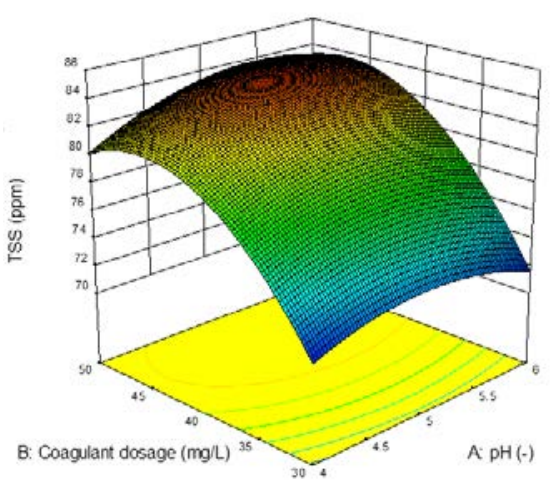

(c)

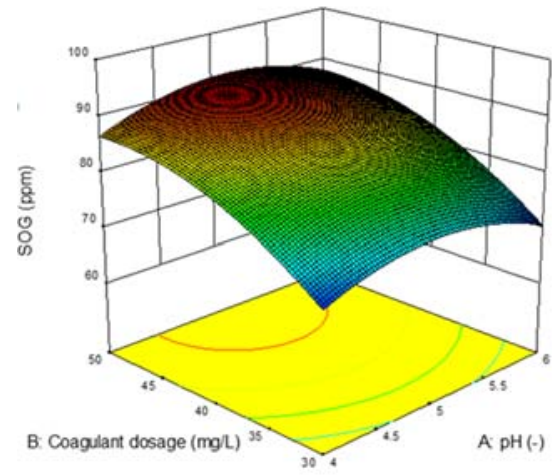

(b)

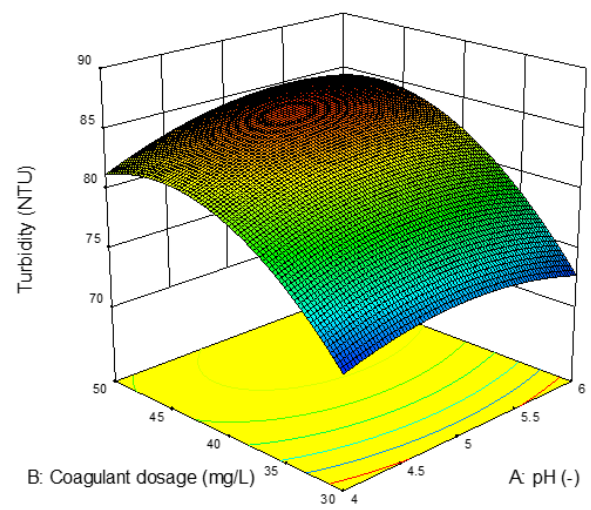

(d)

Figure 3: (a) 3D plot for COD response - effects of $\mathrm{pH}$ and coagulant dosage at constant floatation time (15 minute); (b) 3D plot for SOG response - effects of $\mathrm{pH}$ and coagulant dosage at constant floatation time (15 minute); (c) 3D plot for TSS response - effects of $\mathrm{pH}$ and coagulant dosage at constant floatation time (15 minute); (d) 3D plot for turbidity response - effects of $\mathrm{pH}$ and coagulant dosage at constant floatation time (15 minute).

\section{CONCLUSION}

The operating conditions suitable for the chemical changes and the specific water quality was successfully performed by using a complete mimic WWTP (DAF jar test). The acidification and coagulation before DAF helped improve the effluent treatment, water quality and value added through the recovered oil and water recycled with less downstream cost. The use of the RSM coupled with the BBD provided efficient metrics with a smaller number of experimental data fitted on regression equations with accuracy. The empirical response model predictions were consistent with the experimental data and thus there exists a correlation between the operating factors and response water quality. The $3 \mathrm{D}$ response surface helps to identify the effect of the main factor in the system by visualising their interactions towards the response. To assist the process engineer in decision making on a 
large scale, the main factor to control was the coagulant dosage while the optimum $\mathrm{pH}$ and floatation time were kept constant at 5 and 15 minutes respectively. In addition, the optimum coagulant dosage using the RSM was $49 \mathrm{mg} / \mathrm{L}$ while that of the OFAT was $50 \mathrm{mg} / \mathrm{L}$ with over $80 \%$ of the contaminants removed. Therefore, application of RSM for optimisation of industrial WWTP was seen to be significant over OFAT due to the option to evaluate and visualise the interactional effects between the input variables towards the responses with fewer resources required.

\section{ACKNOWLEDGEMENTS}

The authors wish to thank FFS Refiners Research and Development Department and Umgeni Water Process Evaluation Facility (PEF), South Africa, for their joint support in this project.

We also want to acknowledge the following personalities Ms Keshnee Naik (R\&D Chemist) and Mr Theolan Naidoo (Production Supervisor) at FFS Refiners (Pty) Ltd and Mr Lidenlani Sibiya (Process Engineer) at Umgeni Water for facilitating this project with their expertise.

\section{REFERENCES}

[1] Van Zyl, H., Bam, W. \& Steenkamp, J., eds, Identifying barriers faced by key role players in the South African manganese industry. Institute for Industrial Engineering Conference, 2016.

[2] Li, X., Liu, J., Wang, Y., Xu, H., Cao, Y. \& Deng, X., Separation of oil from wastewater by coal adsorption-column flotation. Separation Science and Technology, 50(4), pp. 583-591, 2014.

[3] Wang, J.-P., Chen, Y.-Z., Ge, X.-W. \& Yu, H.-Q., Optimization of coagulationflocculation process for a paper recycling wastewater treatment using response surface methodology. Colloids and Surfaces A: Physicochemical and Engineering Aspects, 302(1], pp. 204-210, 2007.

[4] Zouboulis, A.I. \& Avranas, A., Treatment of oil-in-water emulsions by coagulation and dissolved-air flotation. Colloids and Surfaces A: Physicochemical and Engineering Aspects, 172(3), p. 153, 2000.

[5] Woodard \& Curran Inc., Industrial Waste Treatment Handbook, ButterworthHeinemann: Burlington, VT, 2011.

[6] Tir, M. \& Moulai-Mostefa, N., Optimization of oil removal from oily wastewater by electrocoagulation using response surface method. Journal of Hazardous Materials, 158(1), pp. 107-115, 2008.

[7] Saththasivam, J., Loganathan, K. \& Sarp, S., An overview of oil-water separation using gas flotation systems. Chemosphere, 144, pp. 671-680, 2016.

[8] Abdel Megid, M.H., Amer, A.A.R. \& Elsayed, K.H., Coagulation and dissolved air floatation for treatment of oil water emulsion. International Journal of Engineering Sciences, 3(12), pp. 120-129, 2014.

[9] Mecha, A.C., Onyango, M.S., Ochieng, A., Fourie, C.J.S. \& Momba, M.N.B., Synergistic effect of UV-vis and solar photocatalytic ozonation on the degradation of phenol in municipal wastewater: A comparative study. Journal of Catalysis, 341, pp. 116-125, 2016.

[10] Mousa, K.M. \& Hadi, H.J., Coagulation/flocculation process for produced water treatment. International Journal of Current Engineering and Technology, 6(2), pp. 550-555, 2016. 
[11] Megid, M.H.A., Amer, A.A.R. \& Elsayed, K.H., Coagulation and dissolved air floatation for treatment of oil-water emulsion. International Journal of Engineering Sciences, 3(12), pp. 120-129, 2014.

[12] Daud, N.M., Sheikh Abdullah, S.R., Abu Hasan, H. \& Yaakob, Z., Production of biodiesel and its wastewater treatment technologies: A review. Process Safety and Environmental Protection, 94, pp. 487-508, 2015.

[13] Berné F., Cordonnier, J. \& Balvet, B.B., Industrial Water Treatment: Refining, Petrochemicals and Gas Processing Techniques, Gulf Professional: Houston, TX, 1995.

[14] Painmanakul, P., Sastaravet, P., Lersjintanakarn, S. \& Khaodhiar, S., Effect of bubble hydrodynamic and chemical dosage on treatment of oily wastewater by Induced Air Flotation (IAF) process. Chemical Engineering Research and Design, 88(5-6), pp. 693-702, 2010.

[15] Li, N., Hu, Y., Lu, Y.Z., Zeng, R.J. \& Sheng, G.P., Multiple response optimization of the coagulation process for upgrading the quality of effluent from municipal wastewater treatment plant. Scientific Reports, 6, p. 26115, 2016.

[16] Khannous, L., Abid, D., Gharsallah, N., Kechaou, N. \& Mihoub, N.B., Optimization of coagulation-flocculation process for pastas industry effluent using response surface methodology. African Journal of Biotechnology, 10(63), pp. 13823-13834, 2011.

[17] Pambi, R. \& Musonge, P., Application of response surface methodology (RSM) in the treatment of final effluent from the sugar industry using Chitosan. WIT Transactions on Ecology and the Environment, 209, pp. 209-219, 2016. 